Kaligayeva Nadiya,

Listener of Magistracy of specialty "Civil Service", chief specialist in the Information and Legal Support

Department, the Public, Department of Internal Policy, Donetsk Regional State Administration

Khaletska Alina,

Doctor's Degree in Public Administration, Professor,

Volyn Institute of Economics and Management, Lutsk

\title{
SOME ASPECTS OF EFFECTIVE FUNCTIONING OF THE PERSONNEL COMPONENT OF THE AUTHORITIES: ANTI-CRISIS APPROACHES
}

The article analyzes the conditions and factors of executive bodies and local authorities in the context of their staffing. Foreign experience of personnel management in the public and local administration for its use at the appropriate levels has been considered. Recommendations for improving the procedures of personnel training, selection and appointment of civil servants, including skills development have been elaborated.

Keywords: staffing; personnel management; recruitment procedures; civil servants.

() Калігаєва Надія, Халецька Аліна

Надійшла до редакції 09.04.2015

\section{УДК 35.081 .7}

\section{КАСПЕРСЬКААНАСТАСІЯ,}

слухач магістратури спеціальності "Державна служба"

Донеиького державного університету управління,

заступник начальника юридичного відділу Артемівської міської ради

\section{ХАЛЕЦЬКА АЛІНА,}

доктор наук з державного управління, професор,

завідувач кафедри менеджменту організачій та зовнішньоекономічної діяльності

Волинського інституту економіки та менеджменту, м. Луиьк

\section{ПРОБЛЕМНІ ПИТАННЯ ПРОЦЕДУРИ ДОБОРУ КАДРІВ В ОРГАНАХ МІСЦЕВОГО САМОВРЯДУВАННЯ}

\begin{abstract}
У статті проаналізовані сучасні вимоги законодавства України до процедури добору кадрів в органи місцевого самоврядування. Особливості проведення перевірок щодо кандидатів на посади місцевого самоврядування показано у світлі законодавства про очищення влади та боротьбу з корупцією. Визначені актуальні проблемні питання, 3 якими стикаються кадровики при прийнятті на роботу претендентів на посади "ззовні" та при переведенні державних службовців, або прирівняних до них посадових осіб. Запропоновані шляхи вдосконалення добору кадрів на службу в органах місцевого самоврядування.
\end{abstract}

Ключові слова: кадрова складова; місцеве самоврядування; люстрація; боротьба з корупцією.

Постановка проблеми та стан її вивчення. Добір кадрів в органи місцевого самоврядування $є$ багаторічним налагодженим механізмом, закріпленим на законодавчому рівні. Однак сучасне законодавство України щоразу встановлює нові вимоги до цієї процедури. Ще недавно кадровики стикалися з проблемою реалізації на практиці проведення спеціальної перевірки відносно претендентів на посади згідно Закону України "Про засади запобігання і протидії корупції", а вже сьогодні зміни в законодавстві (прийняття Закону України "Про очищення влади" та набрання чинності нового Закону України "Про запобігання корупції") вимагають від кадрових служб якнайшвидшої апробації нових механізмів здійснення перевірок кандидатів на посади.

Актуальність статті зумовлена тим, що антикорупційна політика та люстрація влади на сьогодні $€$ пріоритетними напрямками внутрішньої політики держави. її результативність у цих напрямках та в цілому залежить від підтримки та ефективного застосування антикорупційних заходів та заходів із очищення не тільки 
в державних органах влади, а й в органах влади на місцях. Першочерговим кроком $€$ недопущення до роботи в органах влади "заплямованих" осіб. Тому саме реалізація антикорупційних та люстраційних заходів на стадії прийому на роботу мають вагомий вплив на кадровий склад органів місцевого самоврядування як існуючий, так і на кандидатів на відповідні посади. Однак, плинність змін у чинному законодавстві щодо перевірок претендентів на посади місцевої влади та низький рівень актуалізації механізмів здійснення цих перевірок значно ускладнюють роботу кадровиків та дуже часто ставлять перед ними "питання без відповідей", наприклад, як у межах встановлених законодавством строків, не порушуючи конституційних прав претендента, забезпечити проведення необхідних перевірок щодо нього, коли колізія існує не тільки в нормативно-правових актах, що регулюють ці відносини, але і в діях органів, на яких покладено обов'язок реалізації цих актів на практиці?

Мета статті - визначити актуальні проблемні питання нормативно-правового поля, у межах якого відбувається добір кадрів в органи місцевого самоврядування на сучасному етапі та запропонувати шляхи вдосконалення цього процесу.

Виходячи з мети статті постає необхідність вирішення наступних завдань: визначити та проаналізувати законодавчу базу, яка регулює питання прийняття на роботу кандидатів на посади органів місцевого самоврядування; з'ясувати сучасні проблемні питання при впровадженні нормативних актів під час добору кадрів; розглянути сутність проведення перевірок щодо претендентів на посади; сформулювати пропозиції щодо вирішення визначених проблемних питань.

Виклад основного матеріалу. Добір персоналує початковим, а тому одним з найбільш важливих етапів процесу управління персоналом; від успішності цього процесу значною мірою залежить, хто був відібраний для роботи в органах місцевої влади. Органи місцевого самоврядування в питаннях кадрової роботи здійснюють свою діяльність відповідно до Законів України "Про державну службу" та "Про службу в органах місцевого самоврядування".

Проходження служби в органах місцевого самоврядування відбувається згідно з чіткими приписами законодавства. Прийняття на посади осіб місцевого самоврядування здійснюється відповідно до Порядку проведення конкурсу на заміщення вакантних посад державних службовців, затвердженого постановою Кабінету Міністрів України від 15.02.2002 № 169 [5] та Загального порядку проведення іспиту кандидатів на заміщення вакантних посад державних службовців, затвердженого наказом Головного управління державної служби України від 08.07.2011 №164 [4], на підстав яких розробляються власні порядки та положення.

Ці нормативно-правові акти покликані фоормувати дієздатний кадровий потенціал, залучати на службу висококваліфрікованих спеціалістів, запобігати рецидивам непрофесіоналізму та некомпетентності під час формування кадрового потенціалу. Даними нормативами запроваджений механізм прийому на службу на конкурсній основі шляхом складання претендентами іспиту з перевірки знань положень Конституції України, Закону України "Про державну службу", антикорупційного законодавства і питань на перевірку знання законодавства з урахуванням специфіки функціональних повноважень відповідного органу [4]. Аналіз цих нормативно-правових актів свідчить, що вони містять лише загальні положення про проведення конкурсу на заміщення вакантних посад, а вирішення конкретних питань на місцях викриває невизначеності у цих актах. А тому кадровим службам місцевих органів влади необхідно проводити величезну аналітичну роботу і створювати розгорнуту процедуру набору на службу.

Звичайно, зазначені нормативи є важливою складовою у питанні здійснення кадрової політики в Україні в цілому і насамперед у доборі кадрів на службу в органах місцевого самоврядування але, на мою думку, це однобоке вирішення питання. Добір справді професійних кадрів на службу місцевого самоврядування необхідно здійснювати не лише на основі знання претендентами законодавчих актів, а більше на основі їх здатності й спроможності виконання посадових обов'язків на певній посаді. Законодавство надає можливість здійснити перевірку такої здатності шляхом проведення із кандидатом співбесіди, однак механізм проведення співбесіди законодавчо не врегульований. Тому в більшості органів місцевого самоврядування цей захід носить формальний суб'єктивний характер, результати якого не можна враховувати як вагомі при прийнятт рішення та які складно оскаржити кандидату на посаду, у разі незадоволення ними. Особливого значення в цьому напрямку набуває питання вивчення, засвоєння, трансформації і адаптації іноземного досвіду, накопиченого в області управління персоналом взагалі і процесу добору зокрема. Саме у цьому напрямку необхідно здійснювати пошук вирішення даної проблеми урядовцям спільно із науковцями України.

Обов'язковою умовою при прийнятті на роботу до органів місцевого самоврядування $€$ проведення спеціальної перевірки кандидатів згідно антикорупційного законодавства та перевірки згідно Закону України "Про очищення влади". Зазначені перевірки є порівняно новими явищами в процедурі добору кадрів в органи місцевого самоврядування.

Українська боротьба із корупцією вже має окрему історію. Багатостраждальне антикорупційне законодавство змінювалось 3 кожною зміною влади. Так, починаючи з 2009 року, щодва роки Верховною Радою України приймався новий антикорупційний закон та низка підзаконних актів до нього. Вимоги щодо проведення спеціальної перевірки стосовно осіб, які претендують на зайняття посад, пов'язаних з виконанням функцій держави або органів місцевого самоврядування, вперше були задекларовані в Законі України "Про засади запобігання та протидії корупції" 2009 року. Чинним Законом України від 14.10.2014 № 1700-VII "Про запобігання корупції" [1] вимога щодо проведення спеціальної перевірки збережена, однак механізм її проведення викликає серед кадровиків низку проблемних питань. Основними з них є:

Низький рівень актуалізації чинного законодавства. 3 уведенням в дію Закону України від 14.10.2014 № 1700-VII "Про запобігання корупції" набрав чинності Порядок проведення спеціальної перевірки стосовно осіб, які претендують на зайняття посад, які передбачають зайняття відповідального або особливо відповідального становища, та посад з підвищеним корупційним ризиком (постанова КМУ від 25.03.2015 № 171) [7]. Проте Порядок проведення спеціальної перевірки відомостей щодо осіб, які претендують на зайняття посад, пов'язаних із виконанням функцій держави або місцевого самоврядування (указ Президента України від 25.01.2012 № 33/2012) досі не скасований [6].

Несвоєчасна розробка та прийняття підзаконних актів, якими повинні керуватись кадрові служби при проведенні перевірки та їх роздрібненість за рахунок 
різноманітності органів, відповідальних за їх прийняття. Так, новим Порядком проведення спеціальної перевірки зазначено, що перевірку проходять тільки кандидати на посади, які передбачають зайняття відповідального або особливо відповідального становища, та посад з підвищеним корупційним ризиком. Перелік посад, які передбачають зайняття відповідального або особливо відповідального становища визначає Кабінет Міністрів України та надає їх у зазначеному Порядку. Перелік посад з підвищеним корупційним ризиком Кабінет Міністрів України доручає затвердити Національному агентству з питань запобігання корупції [7]. Поперше, на сьогоднішній день досі не розпочало свою роботу Національне агентство з питань запобігання корупції. За словами Міністра юстиції України П. Петренко, його повноцінне функціонування буде розпочате лише наприкінці 2015 року. По-друге, через відсутність цього виконавчого органу, досі відсутній перелік посад з підвищеним корупційним ризиком.

Це призводить до того, що перед кадровиками постають питання, чи проводити таку перевірку відносно кандидатів на зайняття всіх посад з метою "дії на попередження" (задля того, щоб не проводити додаткові перевірки в терміновому порядку після затвердження переліку) та кому надсилати запити щодо наявності в Єдиному державному реєстрі осіб, які вчинили корупційні або пов'язані з корупцією правопорушення, відомостей про претендента на посаду, а також щодо достовірності відомостей, зазначених особою у декларації особи, уповноваженої на виконання функцій держави або місцевого самоврядування, за минулий рік, як того вимагає п.п.5 п.9 Порядку [7].

Також, проблемним $є$ питання строків встановлених для проведення зазначеної перевірки. Новим Порядком визначено 9 органів виконавчої влади (1 з яких ще не створено) для надсилання відповідних запитів щодо перевірки та встановлено строк проведення перевірки, що не перевищує 25 календарних днів з дати надання згоди на її проведення. Однак аналізуючи процес здійснення спеціальної перевірки згідно Порядку, затвердженого указом Президента України від 25.01.2012 № 33/2012, який досі чинний, при умові надсилання запитів до 5-ти обов'язкових органів виконавчої влади та встановленому 15-ти денному строку для здійснення всієї перевірки, строки проведення такої перевірки тривали від 25 календарних днів до 1-1,5 місяця. Це призводило до того, що органи місцевого самоврядування не могли ефективно здійснювати свою діяльність та надавати громаді відповідні послуги, оскільки при фрактичній наявності спеціаліста на вакансію, його допуск до роботи, за відсутності результатів спеціальної перевірки, був протизаконним. Також затримка отримання результатів перевірки сприяла відтоку кадрового потенціалу органів місцевого самоврядування, оскільки фактично на час здійснення спеціальної перевірки кандидат залишався без роботи та джерела доходів.

Як не дивно, проблеми у кадрових служб виникають не лише при проведенні спеціальних перевірок щодо кандидатів на посади органів місцевого самоврядування, але і відносно кадрового ресурсу, який "мігрує" в органах державної влади та місцевого самоврядування. Пункт 4 нового Порядку зазначає, що стосовно претендентів на посади, які вже проходили спеціальну перевірку, під час призначення в порядку переведення на посаду до іншого державного органу, органу місцевого самоврядування спеціальна перевірка не проводиться [7]. Але $є$ незрозумілим чи прирівнюються ре- зультати спеціальної перевірки, проведеної відносно посадовця за старим Порядком, до результатів спеціальної перевірки за новим Порядком, оскільки кількість органів до яких необхідно надсилати запити збільшилась практично вдвоє.

Окрему увагу хочеться приділити, перевірці достовірності відомостей, що подаються особами, які претендують на зайняття відповідних посад, щодо застосування заборон, передбачених Законом України "Про очищення влади". Здійснення цієї перевірки було запроваджене наприкінці 2014 року. Заборони, про які йде мова, стосуються займання посад щодо яких здійснюється очищення влади (люстрація) на певний строк [2]. Порядок проведення кадровиками зазначеної перевірки затверджений постановою Кабінету Міністрів України від 16.10.2014 № 563 "Деякі питання реалізації Закону України "Про очищення влади" [3]. Закон переважно стосується посадових осіб органів державної влади. У частині місцевого самоврядування дія Закону поширюється на посадових осіб (крім виборних посад) місцевого самоврядування та на осіб, які претендують на зайняття посад в органах місцевого самоврядування. Тобто, Закон поширюється лише на середню та нижню керівну ланку та фахівців органів місцевого самоврядування. Щодо посадових осіб місцевого самоврядування, то у силу Закону заборона на 10 років обіймати відповідні посади стосується лише осіб, які працювали на керівних посадах Комуністичної партії колишнього СРСР та союзних республік, ЦК ЛКСМУ, працювали в органах безпеки колишнього СРСР. Заборона обіймати вказані посади в органах місцевого самоврядування (крім виборних посад) протягом п'яти років застосовується лише за рішенням суду у разі встановлення фактів вчинення визначених злочинів або адміністративних правопорушень як основне або додаткове покарання [2]. Таким чином, найбільший обсяг роботи стосуватиметься перевірки достовірності відомостей декларацій про майно, доходи, витрати і зобов'язання фрінансового характеру.

На підставі аналізу Закону можна зробити висновок, що він незначною мірою стосується місцевого самоврядування, однак робота щодо його реалізації вже розпочата з жовтня 2014 року і значна кількість запитів до визначених Законом органів вже надіслана. Однак, вже у березні 2015 року процедура здійснення такої перевірки зазнала змін в частині зменшення органів до яких надсилатимуться запити. Здавалося це повинно облегшити роботу кадровика, однак на сьогоднішній день $€$ актуальною проблема неможливості закінчення процедури перевірки, яка розпочата до внесення відповідних змін в законодавстві, оскільки органи, що були виключені із списку обов'язкових для надсилання запитів, не надають відповідей на запити посилаючись на зміни у Порядку.

Поряд із цим, ні законодавством про люстрацію ні антикорупційним законодавством не передбачений механізм впливу на органи виконавчої влади, які здіяні в проведенні зазначених перевірок, та не визначена їх відповідальність.

Проведене дослідження з проблем та пріоритетів добору кадрів на службу в органах місцевого самоврядування, його узагальнення та аналіз дають підставу розробити пропозиції та рекомендації, які можуть бути використані як для теоретичних методик вдосконалення добору кадрів, так і в практичній діяльності кадрових служб. Основними з них є:

Викорінення формального, не ділового підходу у проведенні конкурсного відбору, розробка конкретних 
критеріїв, норм, стандартів при прийомі на роботу на посади місцевого самоврядування, які б забезпечували об'єктивну і комплексну оцінку не тільки професійних, але і особистих якостей претендентів. Оскільки, як свідчить практика, характерним для багатьох посадовців $€$ невміння самостійно ухвалювати рішення, адаптуватися та визначати пріоритети в критичних, стресових ситуаціях, застосовувати прийоми наукового прогнозування, вирішувати конфрлікти . Не всі з працюючих на службі можуть піднятися до рівня перспективного бачення проблем, зрозуміти, що їм бракує знань технології державного управління, з активного маркетингу. Від кадрів, їх професійної і ділової компетентності, нового мислення і вміння працювати в сучасних умовах, залежить прийняття продуманих, обґрунтованих рішень і здатність реалізувати їх на практиці.

Перехід на новітні форми добору кадрів: впровадження технологій проведення тестування та стажування зі складанням іспитів; проведення структурованого інтерв'ю з кандидатом, на основі попередньо розроблених обов'язкових і додаткових питань.

Встановлення критичних вимог до членів конкурсної комісії, в т.ч. щодо звітності за добір кадрів, а також впровадження механізму їх стимулювання до якісного добору кадрів.

А також створення єдиної комплексної систематизованої правової основи добору кадрів в органи місцевого самоврядування. 3 визначенням як на державному так і місцевому рівні вузького кола органів та осіб, задіяних у цьому процесі та чітким нормативним визначенням рівня відповідальності кожного з них. Оскільки тільки міцна правова основа надасть можливість створити корпус службовців нового типу, заснований на професіоналізмі осіб, які в ньому працюють, мають високий рівень загальнокультурної освіченості та володіють сучасними інформаційними технологіями.

\section{Висновки}

Питання кадрового забезпечення органів місцевого самоврядування необхідно вирішувати комплексно, так як спроби зрушити лише один чи декілька напрямів загальної проблеми не призведуть до необхідних якісних змін. Впровадження таких контролюючих заходів, як проведення антикорупційних та люстраційних перевірок $€$ без сумніву вагомим елементом фрормування прозорої влади, влади для людей, однак механізми їх реалізації не повинні створювати перепони в фрормуванні кадрової політики в цілому, та розвитку такого їі напрямку, як добір кадрів. Тільки системний підхід до управління людськими ресурсами дозволить службі в органах місцевого самоврядування у XXI столітті ефективно забезпечувати потреби суспільства.

\section{ЛПТРАТУРА}

1. Про запобігання корупції : Закон України від 14.10.2014 № 1700-VII [Електронний ресурс]. - Режим доступу : www.portal.rada.gov.ua.

2. Про очищення влади : Закон України від 16.09.2014 № 1682-VII [Електронний ресурс]. - Режим доступу : www.portal.rada.gov.ua.

3. Деякі питання реалізації Закону України "Про очищення влади" : Постанова Кабінету Міністрів України від 16.10.2014 № 563 [Електронний ресурс]. - Режим доступу : zakon.rada.gov.ua.

4. Загальний порядок проведення іспиту кандидатів на заміщення вакантних посад державних службовців : Наказ Головного управління державної служби України від 08.07.2011 № 164 [Електронний ресурс]. - Режим доступу : zakon.rada.gov.ua.

5. Порядок проведення конкурсу на заміщення вакантних посад державних службовців : Постанова Кабінету Міністрів України від 15.02.2002 № 169 [Електронний ресурс]. - Режим доступу : zakon.rada.gov.ua.

6. Порядок проведення спеціальної перевірки відомостей щодо осіб, які претендують на зайняття посад, пов'язаних із виконанням функцій держави або місцевого самоврядування : Указ Президента України від 25.01.2012 № 33/2012 [Електронний ресурс]. - Режим доступу : zakon.rada.gov.ua.

7. Порядок проведення спеціальної перевірки стосовно осіб, які претендують на зайняття посад, які передбачають зайняття відповідального або особливо відповідального становища, та посад з підвищеним корупційним ризиком, і внесення змін до деяких постанов Кабінету Міністрів України : Постанова Кабінету Міністрів України від 25.03.2015 № 171 [Електронний ресурс]. - Режим доступу : zakon.rada.gov.ua.

\section{Касперская Анастасия,}

слушатель магистратуры специальности "Государственная служба"

Донеикого государственного университета управления, заместитель начальника

юридического отдела Артемовского городского совета

\section{Халецкая Алина,}

доктор наук по государственному управлению, профессор,

заведуюшая кафедрой менеджмента организаций и внешнеэкономической деятельности

Вольнского института экономики и менеджмента, г. Луцк

\section{ПРОБЛЕМНЫЕ ВОПРОСЫ ПРОЦЕДУРЫ ОТБОРА КАДРОВ В ОРГАНАХ МЕСТНОГО САМОУПРАВЛЕНИЯ}

В статье проанализированы современные требования законодательства Украины к процедуре отбора кадров в органы местного самоуправления. Особенности проведения проверок кандидатов на должности местного самоуправления показаны в свете законодательства об очищении власти и борьбе с коррупцией. Определены актуальные проблемные вопросы, с которыми сталкиваются кадровики при приеме на работу претендентов на должности "из вне" и при переводе государственных служащих или приравненных к ним должностных лиц. Предложены пути совершенствования отбора кадров на службу в органах местного самоуправления.

Ключевые слова: кадровая составляющая; местное самоуправление; люстрация; борьба с коррупцией. 
Kasperska Anastasiia,

Master's student of "Civil Service",

Donetsk State University of Management,

Deputy Head of the Legal Department Artyomovsk City Council

Khaletska Alina,

Doctor's degree in Public Administration, Professor,

Volyn Institute of Economics and Management, Lutsk

\section{CHALLENGES OF STAFF SELECTION PROCEDURES IN THE LOCAL GOVERNMENT}

The article examines modern requirements of Ukrainian legislation to the staff selection procedure in the local governments. The paper depicts the features of checks on candidates for local government focusing on the legislation on purifying government and fight corruption. The paper explores tests facing candidates for the posts in the local government, considering the legislation on the clarification of the power and the fight against corruption. The research determines the current problems faced by personnel officers at the stage of hiring foreign candidates and conversing public servants or the officials equated to them. The paper suggests the ways to improve the personnel selection for serving in local self-governments.

Keywords: human resources component; local government; lustration; the fight against corruption.

(C) Касперська Анастасія, Халецька Аліна

Надійшла до редакції 27.04.2015

\section{УДК 314.72}

\section{КОРОБКА ІРИНА,}

слухач магістратури спечіальності "Державна служба"

Донецького державного університету управління,

заступник начальника відділу бухгалтерського обліку Маріупольської міської ради

ПАВЛЮК ВАЛЕРІЙ,

кандидат наук з державного управління, доцент, дочент кафедри державного управління та управління освітою Київського університету ім. Бориса Гринченко, м. Київ

\section{ОРГАНІЗАЦІЙНО-ПРАВОВІ ЗАСАДИ СОЦІАЛЬНОГО ЗАХИСТУ ПЕРЕСЕЛЕНЦІВ (ВНУТРІШНЬО ПЕРЕМІЩЕНИХ ОСІБ) ЯК ОСНОВА РЕАЛІЗАЦІї СОЦІАЛЬНОÏ ПОЛІТИКИ ДЕРЖАВИ}

У статті проаналізовано нові тенденції соціальної політики, спрямовані на підтримку внутрішніх переселенців в Україні. Уточнюються мінімальні стандарти соціальної допомоги для даної категорії громадян та визначаються основні принципи соціальної підтримки. Розглянуто сутність соціальної політики при наданні адресної допомоги та зміст понять "внутрішньо переміщена особа", "адресна допомога". Показано роль та направленість державної соціальної підтримки внутрішньо переміщеним особам.

Ключові слова: соціальна політика; внутрішньо переміщена особа; адресна допомога.

Постановка проблеми і стан її вивчення. В узагальненому вигляді діяльність держави із задоволення соціальних потреб людей визначається як її соціальна політика. У період проведення антитерористичної операції держава має вирішувати вчасно ряд проблемних питань, що не було враховано раніше при визначенні соціальної політики, та перекроювати державний бюджет для вдосконалення соціальної політики, а також підтримки переселенців із зони АТО.

Актуальність статті зумовлена тим, що на загальнонаціональному рівні соціальна політика $€$ одним з найважливіших напрямів внутрішньої політики держави, 